OPEN ACCESS

Edited by:

Yunrong Chai,

Northeastern University, United States

Reviewed by:

Munusamy Madhaiyan,

Temasek Life Sciences Laboratory,

Singapore

Fei Gao,

University of Arkansas, United States

${ }^{*}$ Correspondence:

Cuiling Cao

caocuiling@nwsuaf.edu.cn

Specialty section:

This article was submitted to

Plant Microbe Interactions,

a section of the journal

Frontiers in Microbiology

Received: 10 March 2017

Accepted: 23 June 2017

Published: 26 July 2017

Citation:

Wang Z, Xu G, Ma P, Lin Y, Yang X and Cao $C$ (2017) Isolation and

Characterization of a

Phosphorus-Solubilizing Bacterium

from Rhizosphere Soils and Its

Colonization of Chinese Cabbage

(Brassica campestris ssp. chinensis).

Front. Microbiol. 8:1270.

doi: 10.3389/fmicb.2017.01270

\section{Isolation and Characterization of a Phosphorus-Solubilizing Bacterium from Rhizosphere Soils and Its Colonization of Chinese Cabbage (Brassica campestris ssp. chinensis)}

\author{
Zhen Wang, Guoyi Xu, Pengda Ma, Yanbing Lin, Xiangna Yang and Cuiling Cao* \\ College of Life Sciences, Northwest A\&F University, Yangling, China
}

Phosphate-solubilizing bacteria (PSB) can promote the dissolution of insoluble phosphorus $(P)$ in soil, enhancing the availability of soluble $P$. Thus, their application can reduce the consumption of fertilizer and aid in sustainable agricultural development. From the rhizosphere of Chinese cabbage plants grown in Yangling, we isolated a strain of PSB (YL6) with a strong ability to dissolve P and showed that this strain promoted the growth of these plants under field conditions. However, systematic research on the colonization of bacteria in the plant rhizosphere remains deficient. Thus, to further study the effects of PSB on plant growth, in this study, green fluorescent protein (GFP) was used to study the colonization of YL6 on Chinese cabbage roots. GFP expression had little effect on the ability of YL6 to grow and solubilize P. In addition, the GFP-expressing strain stably colonized the Chinese cabbage rhizosphere (the number of colonizing bacteria in the rhizosphere soil was $4.9 \mathrm{lg} \mathrm{CFU} / \mathrm{g}$ ). Using fluorescence microscopy, we observed a high abundance of YL6-GFP bacteria at the Chinese cabbage root cap and meristematic zone, as well as in the root hairs and hypocotyl epidermal cells. High quantities of GFP-expressing bacteria were recovered from Chinese cabbage plants during different planting periods for further observation, indicating that YL6-GFP had the ability to endogenously colonize the plants. This study has laid a solid and significant foundation for further research on how PSB affects the physiological processes in Chinese cabbage to promote plant growth.

Keywords: phosphate-solubilizing bacteria, phosphorus, Chinese cabbage, colonization, rhizosphere

\section{INTRODUCTION}

After nitrogen, phosphorus (P) is the second most essential macronutrient for plant growth (Takahashi and Anwar, 2007). P regulates the functions and activities of many enzymes and affects plant physiology (Schachtman et al., 1998; Bucher, 2007). P deficiency is commonly considered to be an important limiting factor in agricultural production, particularly in China (Yin, 2011). Therefore, massive amounts of phosphate fertilizers have been applied to optimize plant yields in the past century. However, a large portion of the phosphate fertilizer is unavailable to plants because large amounts of P rapidly become immobilized and insoluble (Shenoy and Kalagudi, 2005; 
Viruel et al., 2011). P can be easily dissolved in water, which leads to the loss of $\mathrm{P}$ in the soil and the eutrophication of nearby water bodies, resulting in other consequential pollution problems. In addition, the excessive application of phosphate fertilizers may cause heavy metal accumulation in soil because most of the phosphate fertilizers contain a variety of heavy metals (Ulén et al., 2007). Thus, environmentally friendly substitutes for phosphate fertilizers must urgently be found to avoid the adverse effects of agricultural production (Singh and Reddy, 2011).

In rhizosphere soil, a large number of plant-growthpromoting rhizobacteria (PGPR) are present, particularly phosphate-solubilizing bacteria (PSB), which have the ability to promote plant growth and increase plant production (Fürnkranz et al., 2009; Hanif et al., 2015). These bacteria have the ability to convert insoluble $\mathrm{P}$ into an available form (Hanif et al., 2015). The use of PSB in sustainable agriculture has increasingly attracted the attention of scientists (Hameeda et al., 2008). At present, identified PSB primarily belong to the Pseudomonas, Bacillus, Mycobacterium, and Enterobacter genera, among others (Hanif et al., 2015; Li et al., 2015). Two types of P-solubilization mechanisms in PSB are generally believed to occur. One is the release of organic acids by PSB to dissolve insoluble $\mathrm{P}$, including malic, lactic, acetic, citric, and succinic acids (RodríGuez and Fraga, 1999). The second mechanism is the secretion of enzymes by PSB that are able to degrade insoluble P. Some PSB can even produce plant growth regulators, or phytohormones, such as indole acetic acid (IAA) and gibberellin (GA) (Seo and Park, 2009; Babu et al., 2015).

Many studies have shown that PSB can promote plant growth. PSB can improve the growth of lentil plants with respect to plant height, root length, number of branches, number of seeds per pod, and number of seeds per plant by secreting plant growth promoting substances (Singh et al., 2011). Zhao et al. (2014) isolated 12 strains of PSB in Sichuan and found a strain (SCAK0330), later identified as Burkholderia cepacia, that could solubilize over $450 \mu \mathrm{g} / \mathrm{mL}$ of $\mathrm{P}$, promote the growth of maize, and reduce the infection of small plaque-causing bacteria in corn, thus showing its utility as a biofertilizer and a biocontrol agent. Yu et al. (2011) found that the ability of PSB to solubilize $\mathrm{P}$ is negatively affected by the $\mathrm{pH}$ of the soil and that the absorption of $\mathrm{N}$ and $\mathrm{P}$ by walnut seedlings and the P-solubilization activity of soil significantly improved after the application PSB. In addition, the number of PSB that colonized the rhizosphere was found to be significantly increased, and the soil $\mathrm{pH}$ was reduced. Many more of these microorganisms are present in rhizosphere than in nonrhizosphere soil (Kucey et al., 1989). Thus, the ability of PSB to colonize the rhizosphere determines its overall P-solubilization capacity and its ability to promote plant growth (Ramachandran et al., 2007). Until now, the majority of studies have only focused on the isolation and identification of such bacteria and on other aspects; however, there is still a lack of information on PSB colonization of the rhizosphere, survival patterns, and on the mechanism of P-dissolution, all of which require further systematic studies.

Green fluorescent protein (GFP), which was first isolated from jellyfish (Aequorea), is widely used as a visual reporter in cell and molecular biology (Chalfie, 1994; Gamalero et al., 2004). This protein is used in research for the colonization of microorganisms because they allow for cells to be easily observed by fluorescence microscopy (Prosser, 1994; Zimmer, 2002). At present, GFP is commonly used with bacteria, such as Bacillus and Pseudomonas species, in studies of microorganism colonization (Fernández et al., 2012; Ji et al., 2014; Padda et al., 2015). Antibiotic resistance has been used as a marker to quantify the colonization dynamics of microbes in plant-root systems. Characteristics of the antibiotic markers selected for the PGPR must be determined prior to being used because some soil microorganisms produce different types of antibiotics. A fluorescent and apramycin-resistant Streptomyces strain was observed in roots, and its organization was confirmed as an endogenous bacterium (Bonaldi et al., 2015). However, few studies on the colonization of GFP-labeled PSB in Chinese cabbage have been reported.

In this study, we isolated a strain of PSB (Yangling 6, YL6) from the rhizosphere soil of Chinese cabbage (Brassica campestris ssp. chinensis var. communis Tsen et Lee), which proved capable of solubilizing P. The application of YL6 dramatically reduced the need to use chemical fertilizers and aided in sustainable agricultural development in the study area. Chinese cabbage, a traditional Chinese vegetable, is rich in calcium, potassium, and vitamin $\mathrm{C}$, providing basic nutrients for human dietary needs (Pokluda, 2008). The short growth cycle of Chinese cabbage makes it a perfect experimental model system. Thus, in this study, the effects of YL6 on the growth of Chinese cabbage under field conditions were investigated. To further explore the localization and colonization of YL6 in Chinese cabbage roots and rhizosphere, a GFP-labeled YL6 strain was used.

\section{MATERIALS AND METHODS}

\section{Isolation and Identification of Bacteria}

The study site (N $34^{\circ} 17^{\prime} 9.81^{\prime \prime}$, E $\left.108^{\circ} 04^{\prime} 9.61^{\prime \prime}\right)$ was located in an experimental field of Northwest A\&F University, Yangling, Shaanxi, China. The soil samples were collected from the rhizosphere soil of Chinese cabbage at a depth of 5-15 cm. Rhizospheric bacteria were isolated from one gram of rhizosphere soil by serial dilution plating (Somasegaran and Hoben, 1994) on Pikovskaya's agar plates containing tricalcium phosphate (TCP $10 \mathrm{~g} / \mathrm{L})(\mathrm{Ri}, 1948)$. The plates were incubated at $28 \pm 2{ }^{\circ} \mathrm{C}$ until halos/zones appeared around the colonies. Then, the bacterial strains were purified, and the growth of isolates on screening media was used to compare the P-solubilization abilities. Among several isolated bacterial strains, YL6 showed a remarkable ability to dissolve in organic $\mathrm{P}$ and was selected for further studies.

Yangling 6 was biochemically characterized and identified using Bergey's manual of systematic bacteriology (Sneath et al., 1986). YL6 DNA was obtained by the lysozyme-SDSphenol/chloroform method (Sambrook et al., 1989; Chong, 2001) and was used as template DNA in PCR to amplify the $16 \mathrm{~S}$ rRNA gene using the universal bacterial $16 \mathrm{~S}$ rRNA primers 
(forward: 5'-CGGGATCCAGAGTTTGATCCTGGTCAGAAC GAACGCT- $3^{\prime}$ and reverse: $5^{\prime}$-CGGGATCCTACGGCTACCTT GTTACGACTTCACCCC-3') according to Tan et al. (1997). The $16 \mathrm{~S}$ rRNA gene PCR product was confirmed on a $1 \%$ agarose gel and purified using a DNA Gel Extraction Kit (Qiagen); then, it was ligated to a pMD18-Tvector (Takara, Dalian) and transformed into Escherichia coli DH5 $\alpha$ cells prior to sequencing (Invitrogen $^{\mathrm{TM}}$, Shanghai, China). The derived sequence was compared to known bacterial 16S rRNA gene sequences in the NCBI GenBank database using the BLAST algorithm to identify the isolate.

\section{Determination of P-Solubilization and Organic Acid Production by YL6}

A single colony of each purified isolate was spotted on Pikovskaya's agar plates, incubated at $28 \pm 2{ }^{\circ} \mathrm{C}$, and observed for up to $48 \mathrm{~h}$ for halo/zone formation (Ramachandran et al., 2007). To quantify the soluble $P$ and organic acids present in culture media, $100 \mathrm{~mL}$ of Pikovskaya's broth containing a single colony of each isolate was incubated in a 250-mL Erlenmeyer flask at $28 \pm 2^{\circ} \mathrm{C}$ for $72 \mathrm{~h}$ in a shaker at $180 \mathrm{rpm}$; this experiment was performed in triplicate. After 24, 48, and $72 \mathrm{~h}$ of growth, $20 \mathrm{~mL}$ of each culture was harvested and centrifuged at 13,000 $\times g$ for $10 \mathrm{~min}$ to obtain cell-free supernatants. The supernatants were analyzed for soluble P content and phosphatase activity by the molybdate blue (Mo-blue) (Murphy and Riley, 1962) and sodium phosphate methods, with the absorbance measured at 700 and $405 \mathrm{~nm}$ using a spectrophotometer (Mclachlan, 1980), respectively. The $\mathrm{pH}$ was measured using a $\mathrm{pH}$ meter. All measurements were performed in triplicate.

For the high-performance liquid chromatography (HPLC) analysis of organic acids, the cell-free supernatants were filtered through $0.45-\mu \mathrm{m}$ nylon filters (Millipore, United States). Then, $20 \mu \mathrm{L}$ was injected into the HPLC instrument (Essentia LC-15C, Japan), equipped with a C-18 column, and run at a flow rate of $1 \mathrm{~mL} / \mathrm{min}$ using a 90:10 (v/v) methanol:phosphate buffer $(10 \mathrm{mmol} / \mathrm{L}), \mathrm{pH} 2.7$, as the mobile phase; this process was monitored at $210 \mathrm{~nm}$ (Paavilainen and Korpela, 1993; Qin et al., 2010; Fernández et al., 2012).

\section{Field Experiments}

The objective of this work was to evaluate the phosphate mineralization potential of strain YL6 and its effect on Chinese cabbage growth. The field experiment was performed in an experimental field in the North Campus of Northwest A\&F University. Four treatments were performed, including YL6 fermentation broth (YL6), Pikovskaya's broth (CK1), phosphate fertilizer (CK2), and water (CK0). The test field was divided into 12 plots, each $2 \mathrm{~m}^{2} \times 2 \mathrm{~m}^{2}$. The experiment was conducted in a randomized complete block design with three replications. Before planting, the soil was turned and sowed manually by the dibbling method, with three seeds per hole, with a between-row and between-plant distance of 30 and $8 \mathrm{~cm}$, respectively, in every plot. The Chinese cabbages were harvested after 45 days. Agronomic characteristics, such as plant height, leaf number, root length and volume, and shoot and root dry weight were measured.

\section{Physical and Chemical Properties of Rhizosphere Soils}

The rhizosphere soils were aseptically separated from the roots to assess the physical and chemical properties from each plant treatment. The $\mathrm{pH}$ was measured in a 2:1 water/soil suspension with a $\mathrm{pH}$ meter (Jackson, 1958). Soluble $\mathrm{P}$ was extracted by the bicarbonate method and was then analyzed by the molybdate blue method (Colwell, 1963). The organic matter content was measured using the potassium dichromate colorimetric method (Nelson and Sommers, 1996). The available potassium content was determined using the flame photometer method (Gammon, 1951). The content of nitrate and ammonium nitrogen extracted by a potassium chloride solution was determined with an Auto Analyzer 3 (AA3) (SEAL, Germany) (Crooke and Simpson, 1971; Best, 1976).

\section{Colonies of YL6 in Rhizosphere Soils}

The roots from three replicates per treatment were harvested with the adhered potting soil. Then, $2 \mathrm{~g}$ of rhizosphere soil was added to sterile 50 -mL Erlenmeyer flasks with $18 \mathrm{~mL}$ of sterile water. The flasks were shaken on a rotary shaker for $20 \mathrm{~min}$ at $200 \mathrm{rpm}$, and then $100 \mu \mathrm{L}$ of soil suspension was plated in serial dilutions on Pikovskaya's plates. The colonies showing a clear zone of TCP dissolution were enumerated at the end of the incubation period (Tao et al., 2008).

\section{GFP Labeling of YL6}

\section{Bacterial Strains, Plasmids, and Growth Conditions}

Escherichia coli DH5 $\alpha$ was used as the donor strain for the conjugation of plasmid pMP2444, which carried a GFP gene and a gentamicin $(\mathrm{Gm})$ resistance marker. The E. coli strain HB101 (harboring the helper plasmid pK2013) was used to transport the pMP2444 plasmid. Both pMP2444 and pK2013 were kindly provided by Prof. Gehong Wei, Northwest A\&F University, Yangling, Shaanxi, China. The two strains were grown on Luria-Bertani (LB) medium at $37^{\circ} \mathrm{C}$ (Gilbertson et al., 2007). A triparental conjugation was used to introduce the pMP2444 plasmid into YL6 as described by Poonguzhali et al. (2008). Gentamicin $(50 \mu \mathrm{g} / \mathrm{mL})$ was added to select the recombinant GFP strains as previously described (Gilbertson et al., 2007). A single colony with a transparent halo was picked and used as a template for PCR identification using the primers M13F (5'-TGTAAAACGACGGCCAGT-3') and M13R (5'-CAGGAAACAGCTATGAC- $\left.3^{\prime}\right)$. After an initial denaturation for $5 \mathrm{~min}$ at $95^{\circ} \mathrm{C}, 35$ cycles were performed as follows: denaturation at $95^{\circ} \mathrm{C}$ for $30 \mathrm{~s}$, annealing at $58^{\circ} \mathrm{C}$ for $30 \mathrm{~s}$, and extension at $72^{\circ} \mathrm{C}$ for $30 \mathrm{~s}$. A final extension at $72^{\circ} \mathrm{C}$ for 2 min was performed. The PCR products were detected by agarose gel electrophoresis. Transconjugants isolated from the mating assays were assessed for morphology and motility, and green fluorescence was checked by epifluorescence microscopy (Olympus BX53, Japan) using a filter for green signal (FITC, $488 \mathrm{~nm}$ ). The obtained GFP-expressing strain was named YL6-GFP. 


\section{Comparison of the Parental (YL6) and GFP-Expressing (YL6-GFP) Strains}

The growth curves of YL6 and YL6-GFP were determined by optical density measurements at $600 \mathrm{~nm}\left(\mathrm{OD}_{600}\right)$. Stationary phase cultures were adjusted to an $\mathrm{OD}_{600}$ of 1.0 and were then diluted 1:100 in $\mathrm{LB}$ and incubated at $25^{\circ} \mathrm{C}$ with shaking at $200 \mathrm{rpm}$. Bacterial concentrations $\left(\mathrm{OD}_{600}\right)$ were estimated at 1 , $2,3,4,5,6,7,8,9,10,11$, and $12 \mathrm{~h}$ in duplicate. Soluble P and organic acid contents of YL6-GFP and YL6 cultures utilized the same methods.

\section{Colonization Dynamics of YL6-GFP in Natural Soil}

Soil samples were inoculated with 3, 6, and 9\% (v/w) of the YL6 or YL6-GFP fermentation cultures $(8.3 \mathrm{lg} \mathrm{CFU} / \mathrm{mL})$ in plastic pots $(12 \mathrm{~cm} \times 10 \mathrm{~cm} \times 8 \mathrm{~cm})$ in triplicate and were then cultured in the natural environment $\left(25^{\circ} \mathrm{C}, 22 \%\right.$ relative humidity) in April. The number of YL6-GFP bacteria were estimated by serial dilution plating techniques on Gm-LB medium at 0 , 7, 14, and 21 days. The plates were incubated at $30^{\circ} \mathrm{C}$ for 3 days. YL6-GFP colonies were counted, and the number of bacteria was expressed as the lg CFU/g of rhizosphere soil dry weight.

\section{Pot Experiment}

The fermentation broth of YL6 and YL6-GFP (8.3 $\mathrm{lg}$ CFU/mL) was prepared prior to use. The Chinese cabbage seeds were planted in pots $(24 \mathrm{~cm} \times 17 \mathrm{~cm} \times 16 \mathrm{~cm})$ with $3 \mathrm{~kg}$ of natural soil. Ten Chinese cabbage seeds were planted in each pot, with only five plants/pot kept after seedlings reached the trefoil stage. YL6 (YL6) and YL6-GFP (YL6-GFP) fermentation cultures, Pikovskaya's medium (CK1) and $\mathrm{H}_{2} \mathrm{O}$ (CK0) were applied to the plants at $9 \%(\mathrm{v} / \mathrm{w})$. The plants were grown under natural growth conditions, maintaining a $20 \%$ absolute water content. Twenty days after the application, the plants were harvested, and the plant growth, agronomic characteristics, and soil soluble P content were measured. The number of YL6-GFP cells in the rhizosphere soil was estimated using the serial dilution plating technique on Gm-LB medium at $0,5,10,20$, and 30 days.

\section{Fluorescence Microscopy Observations of Chinese Cabbage Root Colonization after YL6-GFP Application}

The seeds of Chinese cabbages were sterilized with $2 \mathrm{~mL}$ of $0.2 \% \mathrm{NaClO}$ for $5 \mathrm{~min}$ and were then rinsed in $70 \%$ ethanol for $30 \mathrm{~s}$. Subsequently, the seeds were washed five times with sterile water (Narendra et al., 2015). The sterilized seeds were soaked in $8.3 \mathrm{lg} \mathrm{CFU/mL} \mathrm{YL6-GFP} \mathrm{suspensions} \mathrm{for} 30 \mathrm{~min}$. Then, 50 seeds were incubated in water media and kept at $25 \pm 2{ }^{\circ} \mathrm{C}$ under $2000 \mathrm{~lx}$ of illumination intensity with a $16 \mathrm{~h}$ light period. Aseptic culture techniques were used to avoid contamination by other microorganisms. Fluorescence microscopy was used to visualize the internal colonization of fresh Chinese cabbage roots that had been sliced into $1 \mathrm{~cm}$ fragments and mounted on glass slides on the first or third day after planting to confirm the endophytic behavior.

\section{Seed Inoculation and the Growth of Chinese Cabbage Plants}

The surface-sterilized seeds were immersed in the YL6-GFP fermentation culture for $30 \mathrm{~min}$. The seeds were planted in glass bottles $(6 \mathrm{~cm} \times 6 \mathrm{~cm} \times 9 \mathrm{~cm})$ including sphagnum substrate (Pindstrup, Denmark) in a growth chamber $\left(25^{\circ} \mathrm{C}, 55 \%\right.$ relative humidity in a $16 / 8 \mathrm{~h}$ day/night cycle). A bottle that was only inoculated with water was used as the inoculated control. One-, two-, and three-week-old plants were used to verify the ability of the YL6-GFP to colonize in Chinese cabbage.

\section{Statistical Analysis}

Regression and correlation analyses were performed to determine the relationship among the changes in $\mathrm{pH}$ of medium, soluble $\mathrm{P}$, and organic acid production using the SPSS software package version 16.0 (SPSS, Inc., Chicago, IL, United States). Data were assessed using analysis of variance (ANOVA), and least significant difference (LSD) tests were used at a $5 \%$ probability to compare the differences among treatments (Steel et al., 1981).

\section{RESULTS}

\section{Isolation and Strain Identification}

The bacterial strain YL6 (Bacillus cereus) isolated from rhizosphere soils was a gram-positive (Supplementary Figure S1), motile bacterium with a rod-shaped cell morphology. Colonies of this strain on agar plates were creamy and milky white with regular margins. To identify the isolated strain, a BLAST search of the 16S rRNA gene sequence was performed. The 16S rRNA gene sequence of strain YL6 was submitted to the NCBI GenBank and get accession number KX580383. The results of the BLASTn search showed that the YL6 16S rRNA gene sequence was $100 \%$ identical to a B. cereus strain (Acc. no. KT719671).

\section{Evaluation of YL6 P-Solubilization and Organic Acid Production}

P-solubilization was tested by inoculating YL6 onto Pikovskaya's agar plates for $48 \mathrm{~h}$ and measuring the diameter of the halo/zone around a bacterial colony. The diameter of the YL6 colony was $0.7 \mathrm{~mm}$, and the diameter of the halo/zone was $0.4 \mathrm{~mm}$ (Supplementary Figure S2). To further analyze the P-solubilization activity of YL6, the soluble P content in liquid cultures was evaluated by the Mo-blue method. The amount of $\mathrm{P}$ solubilized by YL6 varied from 10.1 to $13.6 \mu \mathrm{g} / \mathrm{mL}$ (Table 1). At $48 \mathrm{~h}$, the soluble P content reached $13.6 \mu \mathrm{g} / \mathrm{mL}$, at which time the lowest $\mathrm{pH}$ value of the culture (4.0) was observed. At 24, 48, and $72 \mathrm{~h}$, as the soluble $\mathrm{P}$ increased in the liquid cultures, the activity of acid phosphatase was changed too. HPLC analysis showed the presence of different organic acids, such as tartaric, acetic, citric, ascorbic, and lactic acids, during the P- solubilization by YL6 (Table 1).

Among these acids, the contents of citric, acetic, and ascorbic acids were significantly correlated with the soluble $\mathrm{P}$ content ( $R^{2}=0.850, R^{2}=0.982$, and $R^{2}=0.966$, respectively, $P<0.05$ ); 


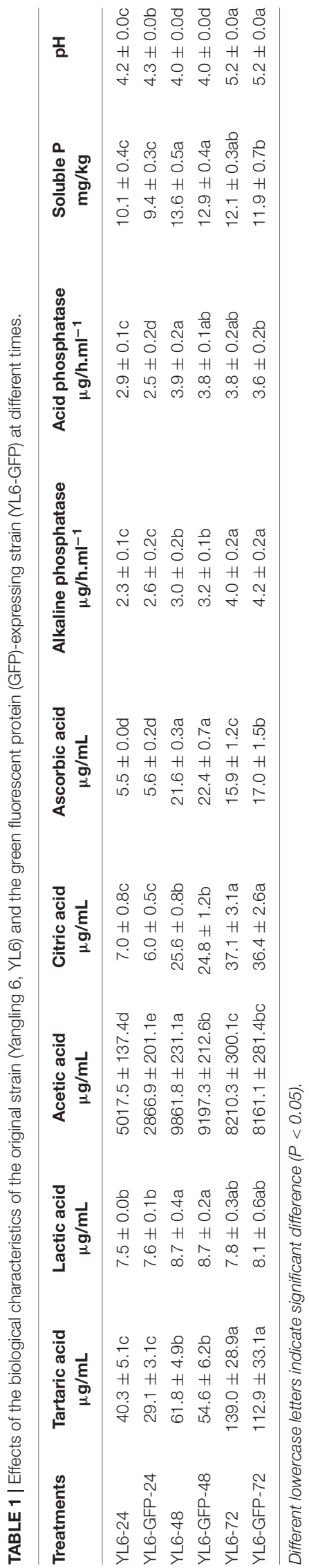

the content of tartaric acid was significantly correlated with the activity of alkaline phosphatase $\left(R^{2}=0.943 ; P<0.05\right)$ and the activity of alkaline phosphatase was positively correlated with the $\mathrm{pH}\left(R^{2}=0.733, P<0.05\right)$ and the content of soluble $\mathrm{P}$ $\left(R^{2}=0.839, P<0.05\right)$.

\section{Effect of YL6 on Chinese Cabbage Plant Growth under Field Conditions}

The effect of the application of YL6 in the field on growth parameters and nutrient uptake of Chinese cabbage plants is shown in Table 2. As the table shows, compared to the noninoculated CK0, the plant height, root length, root volume, and leaf number were significantly increased $(P<0.05)$. Soil inoculated with YL6 promoted the root growth of Chinese cabbage plants. The root volume attained $(1.7 \mathrm{~mL})$ was significantly higher than that obtained with CK0 $(0.5 \mathrm{~mL})$ (Supplementary Table S1). Table 2 shows that the fresh and dry weights of YL6 treated Chinese cabbage plants reached 24.3 and $2.3 \mathrm{~g} /$ plant, respectively, which were significantly higher than those in the CK1, CK0, and CK2 treatments. And we can clearly observe these difference in Supplementary Figure S3.

\section{Influence of the Soil Physical and Chemical Properties and PSB Population in the Chinese Cabbage Rhizosphere}

The effect of YL6 on the $\mathrm{pH}$, soluble $\mathrm{P}$, available potassium, nitrogen (nitrate and ammonium), organic matter, and the number of YL6 bacteria observed in the rhizosphere soil is presented in Table 3. PSB secrete organic acids to reduce the soil $\mathrm{pH}$ and promote the release of available $\mathrm{P}$ from calcareous soil, which is the primary P-solubilization mechanism (Kinraide et al., 2005; Wagh et al., 2014; Chen et al., 2015). After the application of YL6, the soil pH (8.3) was the lowest (Table 3), whereas the PSB count (6.0 lg CFU/g dry weight) was the highest, with $1.7 \%$ more PSB than in the control group $(P<0.05)$ (Supplementary Table S2). The content of soluble P in the soil (5.50 mg/kg) was higher than that in the CK0, CK1, and CK2 treatments. Therefore, the PSB effectively improved the content of available $\mathrm{P}$ in the soil, thus promoting the growth of the Chinese cabbage plants. In addition, after applying YL6, the soluble $\mathrm{P}$, soluble potassium, nitrogen (nitrate and ammonium), and organic matter content were significantly higher than those in the CK0, CK1, and CK2 treatments. These results showed

TABLE 2 | Effects of YL6-GFP on the biomass of Chinese cabbage under field conditions.

\begin{tabular}{|c|c|c|c|c|}
\hline \multirow[t]{2}{*}{ Treatments } & \multicolumn{2}{|c|}{ Fresh weight (g/plant) } & \multicolumn{2}{|c|}{ Dry weight (g/plant) } \\
\hline & Shoot & Root & Shoot & Root \\
\hline CKO & $6.1 \pm 0.3 d$ & $0.6 \pm 0.1 d$ & $0.7 \pm 0.1 d$ & $0.1 \pm 0.0 c$ \\
\hline CK1 & $15.6 \pm 0.3 c$ & $1.3 \pm 0.1 c$ & $1.5 \pm 0.1 c$ & $0.2 \pm 0.0 b$ \\
\hline $\mathrm{CK} 2$ & $18.1 \pm 0.7 b$ & $1.6 \pm 0.1 b$ & $1.7 \pm 0.1 b$ & $0.2 \pm 0.0 b$ \\
\hline YL6 & $24.3 \pm 0.4 a$ & $2.4 \pm 0.1 a$ & $2.3 \pm 0.1 a$ & $0.4 \pm 0.0 a$ \\
\hline
\end{tabular}

Different lowercase letters indicate significant difference $(P<0.05)$. 
TABLE 3 | Influence of YL6 on soils nutrients for Chinese cabbage under field conditions.

\begin{tabular}{|c|c|c|c|c|c|c|}
\hline Treatments & $\begin{array}{c}\text { Soluble P } \\
\mathrm{mg} / \mathrm{kg}\end{array}$ & $\begin{array}{l}\text { Soluble potassium } \\
\mathrm{mg} / \mathrm{kg}\end{array}$ & $\begin{array}{c}\text { Nitrate nitrogen } \\
\mathrm{mg} / \mathrm{kg}\end{array}$ & $\begin{array}{c}\text { Ammonium nitrogen } \\
\mathrm{mg} / \mathrm{kg}\end{array}$ & $\begin{array}{c}\text { Soil organic matter } \\
\qquad \mathbf{g} / \mathbf{k g}\end{array}$ & $\mathrm{pH}$ \\
\hline CKO & $4.3 \pm 0.3 c$ & $130.7 \pm 2.9 d$ & $4.8 \pm 0.4 d$ & $26.7 \pm 1.4 c$ & $25.9 \pm 1.8 c$ & $8.3 \pm 0.0 b$ \\
\hline CK1 & $4.7 \pm 0.3 b$ & $151.3 \pm 3.6 b$ & $6.6 \pm 0.6 b$ & $29.0 \pm 1.2 a b$ & $28.2 \pm 1.5 b$ & $8.3 \pm 0.0 b$ \\
\hline $\mathrm{CK} 2$ & $4.4 \pm 0.3 b c$ & $142.9 \pm 10.8 c$ & $5.7 \pm 0.3 c$ & $28.2 \pm 1.3 \mathrm{a}$ & $26.5 \pm 1.2 \mathrm{bc}$ & $8.4 \pm 0.1 b$ \\
\hline YL6 & $5.5 \pm 0.4 a$ & $164.9 \pm 4.1 \mathrm{a}$ & $8.6 \pm 0.6 a$ & $30.4 \pm 1.6 b c$ & $30.3 \pm 2.4 a$ & $8.3 \pm 0.0 a$ \\
\hline
\end{tabular}

Different lowercase letters indicate significant difference $(P<0.05)$.

that PSB could improve the content of soluble P and improve soil fertility and Ilany and Ali's researches also supported above results (Ilany et al., 2010; Ali et al., 2012).

\section{GFP-Expressing YL6}

A GFP-expressing YL6 strain was constructed for histological studies. The GFP gene was introduced into the YL6 strain by triparental mating. The E. coli strain $\mathrm{DH} 5 \alpha$, carrying the target plasmid (pMP2444), and E. coli HB101, carrying the shuttle plasmid (pK2013), were used to introduce the GFP gene into the recipient YL6 strain. Then, we extracted plasmids inserted GFP and the recombination strain for PCR detection and observed a clear target band at 968 bp (data not show). So they are completely homologous to the known GFP gene. The new recombination strain was named YL6-GFP.

\section{Detection of GFP Expression in the YL6-GFP Strain}

Positive clones that were evenly coated on glass slides and observed by fluorescence microscopy were found to be short rods that emitted green fluorescence. Thus, the GFP gene was shown to have been successfully introduced and expressed in the YL6 strains (Figure 1).

\section{Comparison of the Biological Characteristics of the YL6 and YL6-GFP} Growth Curve

Both the YL6-GFP and parental YL6 strains remained in the lag phase during the first $3 \mathrm{~h}$ of growth (Supplementary Figure S4)
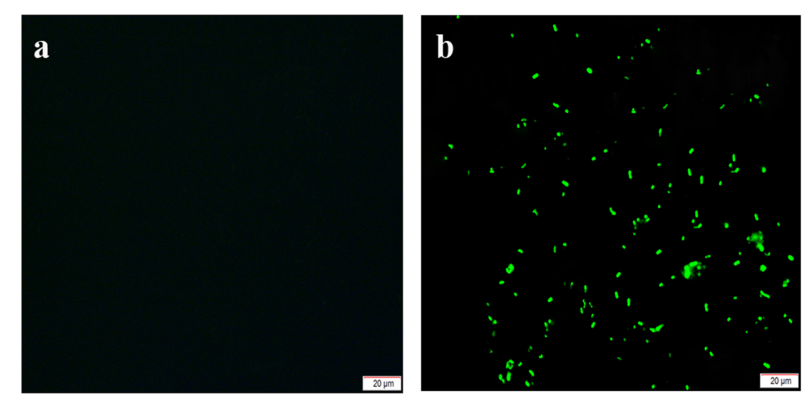

FIGURE 1 | Fluorescence microscopy detection of the green fluorescent protein (GFP)-tagged strain YL6-GFP [a: original strain (Yangling 6, YL6); b: marked strain (YL6-GFP)]. and then spent $5 \mathrm{~h}$ in the logarithmic phase. After $8 \mathrm{~h}$, the two strains reached the stationary phase, but YL6 grew slightly faster than the YL6-GFP strain during the logarithmic and stationary phases. This illustrated that there were some differences between two strains on cell growth resulting from the introduction of the plasmid, possibly due to little more energy consumption in the YL6-GFP strain. However, their growth curves had the same trend; therefore, the exogenous plasmid did not have a detrimental effect on cell growth.

\section{Analysis of P-Solubilization Activity on an Inorganic P Liquid Medium}

YL6-GFP was inoculated into inorganic P liquid medium. The content of soluble $\mathrm{P}$ in this type of media rose initially and then decreased. After $48 \mathrm{~h}$, the content of soluble $\mathrm{P}$ reached $12.6 \mu \mathrm{g} / \mathrm{mL}$ (Table 1). During the same period of growth, the content of soluble P in the YL6-GFP media was consistently slightly lower than that of YL6, which indicated that the exogenous plasmid had a small effect on the activity compared to the parental strain.

The activity of alkaline phosphatase was also positively correlated with the $\mathrm{pH}$ of the GFP-expressing strain $\left(R^{2}=0.758\right.$, $P<0.05)$, and acid phosphatase and soluble $\mathrm{P}$ were positively correlated $\left(R^{2}=0.869, P<0.05\right)$; the secretion of organic acids and the activity of acids or alkaline phosphatase of the GFPexpressing strain were not significantly different compared to the starting strain.

\section{Colonization Dynamics of YL6-GFP in Natural Soil}

To explore the colonization dynamics of YL6-GFP in natural soil, we set up different treatments to observe the number of YL6-GFP bacteria at different periods (Supplementary Figure S5). Because PSB must adapt to the external environment, the number of bacteria decreased with the increase in inoculation days. As Supplementary Figure S5 shows, the bacterial density was highest at 0 days, which was the first day of inoculation. The number of YL6-GFP colonies decreased to 4.9-5.8 lg CFU/g dry weight on the 21st day and remained at this order of magnitude. Therefore, YL6-GFP could stably colonize in the natural soil and display similar growth dynamics to YL6.

\section{Pot Experiment}

The soil soluble P content with the YL6-GFP treatment increased to $14.2 \mathrm{mg} / \mathrm{kg}$ and displayed no obvious differences compared to YL6 $(P<0.05)$; moreover, it was significantly higher than that of CK1 $(13.5 \mathrm{mg} / \mathrm{kg})$ and CK0 $(12.7 \mathrm{mg} / \mathrm{kg})(P<0.05)$ (Supplementary Table S3). The ample $\mathrm{P}$ content in the soil 
promoted root growth, resulting in root expansion into more soil space for assimilating nutrient uptake. The roots of Chinese cabbage treated with YL6-GFP and YL6 were more developed and had root lengths of 12.5 and $12.7 \mathrm{~cm}$, respectively, which were significantly longer than roots with the CK0 and CK1 treatments. A developed root system is beneficial to the development of aboveground parts. The plant height, leaf number, root length, and root volume of the YL6-GFP treated plants increased $16.5,34.9,27.6$, and 260.0\%, respectively, compared to CK0 (Supplementary Table S3). After the application of YL6-GFP, a single plant weight was $18.5 \mathrm{~g}$ higher compared to CK0, whereas the yield of individual plants had increased by $147.4 \%$ $(P<0.05)$ (Supplementary Table S4). Meanwhile, in the samples treated with YL6, the aboveground fresh and dry weight and the underground fresh and dry weight were similar to those in the YL6-GFP treatment, which illustrated that the introduction of the plasmid did not affect the actual application of PSB. In the pot experiment, the number of YL6-GFP in the rhizosphere soil of Chinese cabbage decreased over time. The early stage of inoculation displayed the highest number of YL6-GFP (7.3 lg $\mathrm{CFU} / \mathrm{g}$ at 0 days), but in the rhizosphere soil of Chinese cabbage, the concentration of YL6-GFP was still approximately $4.9 \mathrm{lg}$ $\mathrm{CFU} / \mathrm{g}$ at 30 days (Figure 2).

\section{Observations of Chinese Cabbage Radicle Treated by YL6-GFP}

YL6-GFP was frequently observed to colonize the surface of the cabbage root cap and root epidermal cells on the first or third days (Figures 3A,E). During the process of root tip growth, the extension of pileorhiza is constant, and root elongation is continuous. There were many marked strains gathered in the root cap, because the new cytoderm was so thin that YL6-GFP easily entered the root. A local enlarged photo of the root cap showed that YL6-GFP had moved into its tissue (Figures 3B,F). The two pictures indicated that the labeled bacteria primarily entered the root system via the root cap, which might be the hotspot for YL6-GFP colonization. Many YL6-GFP were found at the intercellular space and intracellular region of the apical

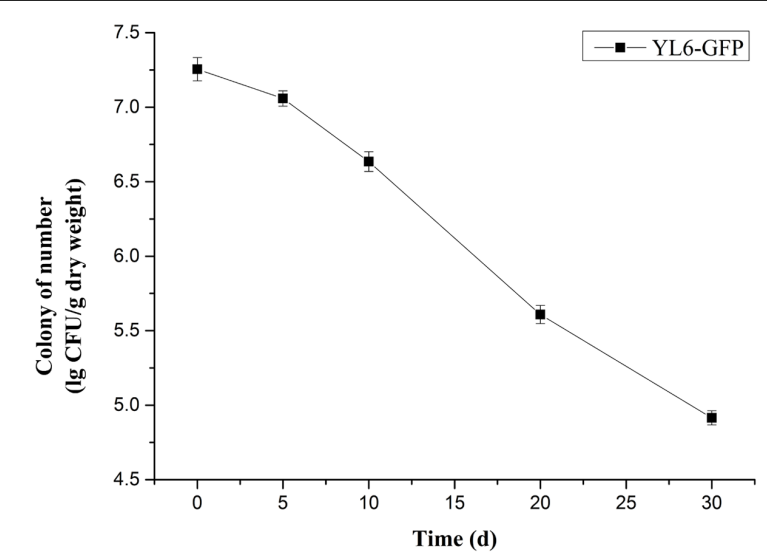

FIGURE 2 | Colonization byYL6-GFP in the rhizosphere soil of Chinese cabbage. meristem zone (Figures 3C,G). Simultaneously, a motion trail of GFP-expressing bacteria were clearly observed in root hair, where cells are long and the cell walls are thin (Figure 3G). The lifecycle of root hair is short. Root hair could enhance the absorption area and secrete acid to help roots take in nutrients, which can transport water and nutritive material into other above ground parts of the plant. There were large number of YL6-GFP in the epicotyl (Figures 3D,H). This phenomenon suggested that GFP-expressing strains might be carried by water (Figures 3I,J) to other plant tissues. Then we made further observations of epidermal cells at higher magnification (Figures 3K,L). A significant amount of YL6-GFP were found in many epidermal cells of the epicotyl. We could infer from the above results that YL6-GFP entered the Chinese cabbage root tissue through the gap of root epidermal cells in the root hair and root cap and was then transported by water in the longitudinal direction to hypocotyl vascular tissue through the vascular bundle in the root.

\section{Mobility of YL6-GFP in Chinese Cabbage}

As Table 4 shows, YL6-GFP could invade the root quickly during the first week when we began the sterile seedling test. Increasing numbers of GFP-expressing cells were found in root tissues, and the number of GFP-expressing bacteria increased to $4.5 \mathrm{lg} \mathrm{CFU} / \mathrm{g}$ dry weight and $4.3 \mathrm{lg}$ CFU/g dry weight in the rhizosphere soil during the third week. Then, the strains moved to leaves in the third week.

\section{DISCUSSION}

$\mathrm{P}$ is an important factor limiting agricultural production (Goldstein, 1951; Asea et al., 1988). Large amounts of P fertilizer added to soil not only increase the cost of agriculture but also cause environmental problems (Shahid et al., 2012; Hanif et al., 2015; Majeed et al., 2015) and are not conducive to the sustainable development of agriculture. PSB have a great ability to transform insoluble $\mathrm{P}$ in the soil into an available form and have great application prospects for eco-agriculture. The secretion of organic acids and chelation are major P-solubilization mechanisms of PSB. The presence of many PSB in the soil is an important index of effective promotion of crop growth and sustainable agricultural development (Fernández et al., 2012).

We isolated YL6 from the rhizosphere of Chinese cabbage as a bacterium with a strong potential to solubilize phosphate. The bacterium was identified as $B$. cereus by $16 \mathrm{~S}$ rRNA sequence analysis, which is a common method used to identify bacterial species (Clarridge, 2004; Coelho et al., 2011). Based on the analysis of the P-solubilization of YL6, the P-solubilization was the highest at $48 \mathrm{~h}$. Recent studies also reported that the content of soluble P does not change over time (Zhao et al., 2014; Li et al., 2015; Osorio and Habte, 2015). This might be because PSB can secrete organic acids to degrade TCP to promote the content of soluble $\mathrm{P}$ in culture medium; thus, the content of soluble $\mathrm{P}$ does not decrease over time. With the increase in culture time and nutrient consumption, the insoluble $\mathrm{P}$ in the culture is converted to a form that plants can absorb (Chatli 

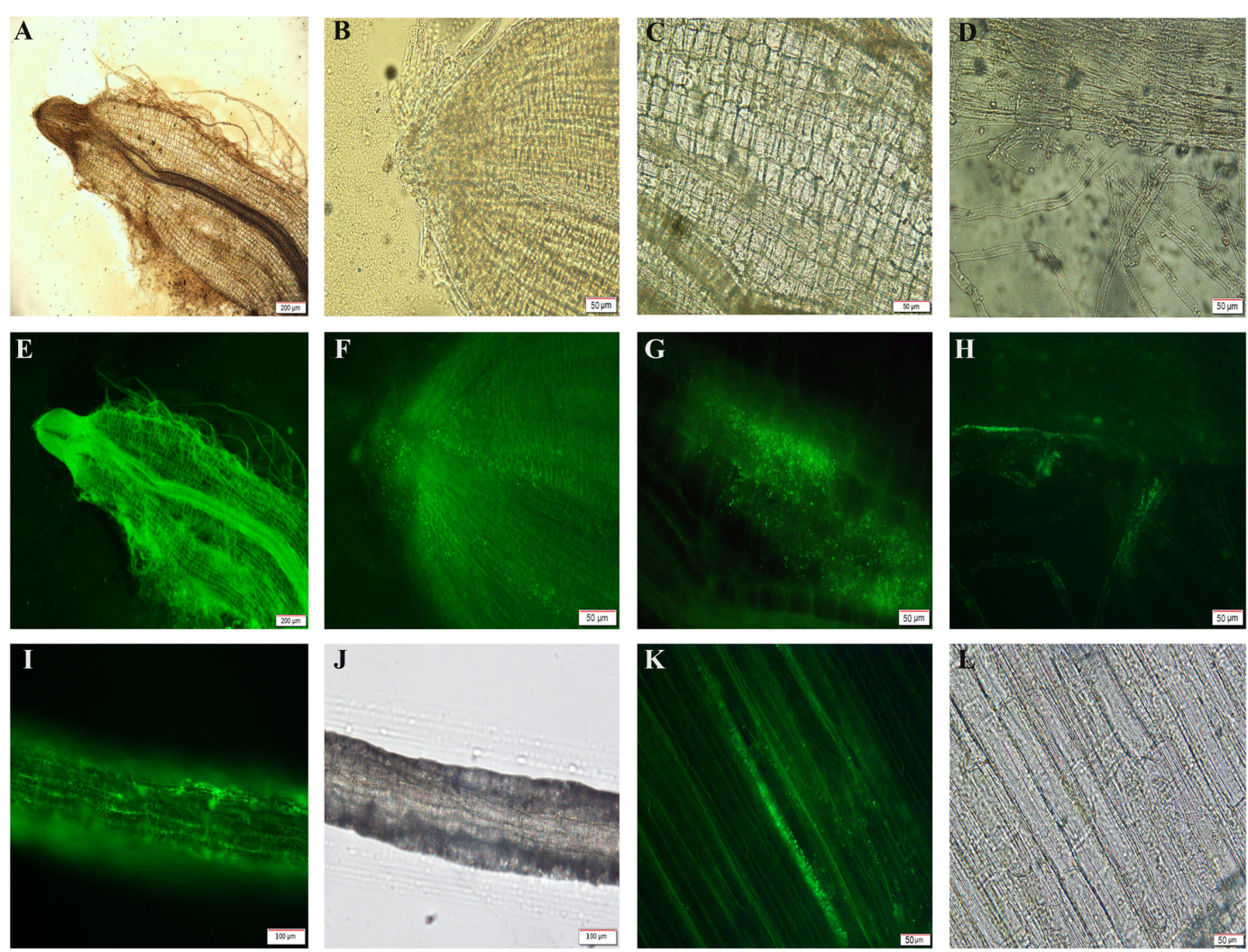

FIGURE 3 | Fluorescence micrograph of the different tissues of Chinese cabbage colonized by YL6-GFP (A,E,B,F, root tip; C,G,D,H, root hairs; I,J, epicotyl; K,L, hypocotyl epidermis).

TABLE 4 | Colonization dynamics of YL6-GFP in leaves, roots and rhizosphere soil of Chinese cabbage.

\begin{tabular}{lccc}
\hline & \multicolumn{3}{c}{ Colonization number of YL6-GFP (Ig CFU/g dry weight) } \\
\cline { 2 - 4 } & 1 week & 2 weeks & 3 weeks \\
\hline Rhizosphere soil & 4.2 & 4.3 & 4.3 \\
Roots & 3.3 & 4.2 & 4.5 \\
Leaves & 0 & 0 & 3.9 \\
\hline
\end{tabular}

et al., 2008). Therefore, the P-solubilization activity declines after peaking. The number of PSB and the culture $\mathrm{pH}$ were found to be negatively proportional with different culture times $\left(R^{2}=-0.737, P<0.05\right)$, and the content of soluble $\mathrm{P}$ was positively correlated with acid phosphatase activity $\left(R^{2}=0.839\right.$, $P<0.05)$, which was also demonstrated in research by Chen and Shahid (Chen et al., 2006; Shahid et al., 2012).

In the field experiment, because the principal mechanism for P-solubilization in soil is lowering the soil $\mathrm{pH}$ via the PSB production of organic acids (Chatli et al., 2008; Badawi, 2010), we found that soluble $\mathrm{P}$ in the soil increased significantly after inoculation with YL6, and the soil $\mathrm{pH}$ decreased markedly. The content of nitrogen (nitrate and ammonium) and organic matter also increased, indicating that PSB could improve soil nutrients. In addition, $\mathrm{P}$ promotes the development of roots; thus, the growth of Chinese cabbage roots was significantly improved after the application of YL6 (Chen et al., 2017). The root is the main organ for absorbing minerals and water and participates in material transport (Shane et al., 2003; Heppell et al., 2015). Therefore, it is easy to understand that the fresh and dry plant weight and plant height were significantly increased with the improved root system. These findings corroborate earlier reports on plants such as the sunflower (Helianthus annuus), cucumber (Cucumis sativus L.), and potato (Solanum tuberosum L.) (Shahid et al., 2014; Hanif et al., 2015).

Green fluorescent protein and other fluorescence markers are valuable tools, allowing colonization by recombinant microorganisms to be visualized via fluorescence microscopy (Luby-Phelps et al., 2003). To obtain a stable genetic transformation, the target gene was introduced into YL6 by a triparental mating (Liu et al., 2012). The GFP-expressing YL6 strain (YL6-GFP) was similar to the original strain (YL6), both in its growth and ability to dissolve P. The ability of PSB survival in the soil is the key to determining its role in the natural environment and is an important basis on which to evaluate PSB colonization ability in the rhizosphere (Shen et al., 2013; Hanif et al., 2015). To detect and quantify PSB colonization in natural (non-sterile) soil, we used a dilution series method and antibiotic resistance to determine the growth and colonization of the bacteria (Brown and Waatti, 1980). In the inoculation 
experiments in natural soil, the YL6-GFP population remained stable for up to 21 days (5.0-5.8 $\mathrm{lg}$ CFU/g of dry soil) after the initial decrease in population density. In the experimental pots, the rhizosphere soil of Chinese cabbage still contained approximately $4.9 \mathrm{lg} \mathrm{CFU} / \mathrm{g}$ after 30 days. It is possible that YL6 quickly established a stable interaction with the host plant roots. Indeed, the reason why the number of PSB was higher than that of other microorganisms in soils is that the presence of the host plant may have greatly affected the survival of PSB that were attracted to the rhizosphere of the growing seedlings (Bashan et al., 1995; Bonaldi et al., 2015). In the pot experiments, YL6-GFP did not display a negative influence on the growth of Chinese cabbage plants. Thus, YL6-GFP and YL6 did not affect this practical application result.

To further explore the mechanism of growth-promoting bacteria, we used fluorescence microscopy to study the distribution of GFP-expressing strains in the roots of Chinese cabbage and the change in the presence of YL6-GFP (Coombs and Franco, 2003; Olivain et al., 2006; Fernández et al., 2012). The fluorescence labeling technique is widely used to observe the colonization of microorganisms in roots or root tips (Schippers et al., 1995; Simons et al., 1996; Anand and Chanway, 2013; Zhao et al., 2013; Chen et al., 2016). There is much research on the colonization of biocontrol bacteria of plants, but little on PSB. Lelis et al. (2014) noted that most Clavibacter michiganensis sub sp. IPO3356 entered tomato (Lycopersicon esculentum Mill.) plant tissues through wounds or during the formation period. Surprisingly, $28-30^{\circ} \mathrm{C}$ is the most suitable condition for microbial activity. The PSB (Ps-5) was also found in the root tissue of the sunflower by Shahid, indicating that Ps-5 might be an endophytic bacterium that promotes crop growth and can enter plant tissue. However, there has not been a long-term study of its ability to survive in the rhizosphere (Shahid et al., 2014). For Bacillus subtilis $\mathrm{P} 2 \mathrm{~b}-2 \mathrm{R}$, when a GFP-expressing strain (P2b-2Rgfp) was applied to canola (Brassica campestris L.) and tomato, P2b-2Rgfp was also observed in the roots and leaves of seedlings 20,30, and 40 days after treatment. GFP-labeled P2b-2R did not affect its biological activity (Padda et al., 2015). A PSB strain that was isolated from soil and engineered to express GFP was also studied by Fernández et al. (2012). The number of colonizing P bacteria ranged from $1.7 \times 10^{7}$ to $7.6 \times 10^{5} \mathrm{CFU} / \mathrm{g}$ over a $0-15$ days period. These authors detected fluorescence labeling in the rhizosphere bacteria but did not conduct further monitoring (Fernández et al., 2012). In our study, YL6-GFP could survive in the natural soil, rhizosphere soil, and roots. YL6-GFP could rapidly colonize the Chinese cabbage root and hypocotyl cells. These phenomena indicated that YL6 might be endophytic, able to enter the plant tissue, and establish interactions with the host to promote plant growth. To further validate our ideas, we cultivated Chinese cabbage under sterile conditions and then found that the biomass significantly increased at 1-, 2-, and 3-weeks, with many YL6-GFP bacteria present in the root tissue.
The colonization ability of microorganisms on roots has a significant influence on establishing an interaction relationship with the host (Chen et al., 2016). PSB can turn insoluble P into soluble P and promote plant growth (Rodríguez et al., 2006; Zhao et al., 2014). The promotion of plant growth by PSB has been confirmed by data gathered in the field and in indoor pot tests. By studying the colonization capability of YL6 on Chinese cabbage using a GFP-expressing YL6 strain, we found that GFP-expressing bacteria were present in the tissue of the Chinese cabbage plants. This research helps us to understand the advantage that PSB provide in plant growth at the cellular level. Research on the colonization of YL6 in Chinese cabbage tissues provides a theoretical foundation for understanding the P-solubilization mechanism of PSB and offers a basis for the application and development of eco-friendly, high-yield agriculture.

\section{AUTHOR CONTRIBUTIONS}

ZW isolated strain YL6, marked strains by GFP, cultivated Chinese cabbages in pot with application of YL6 and YL6-GFP, observed colonization of Chinese cabbages seedling in sterile condition, and drafted the manuscript. GX cultivated Chinese cabbages in field condition and helped ZW finish original manuscript. XY helped ZW use fluorescence microscope take useful photos. CC participated in the discussions of each section of experiments, designed the outline of this and partly supported this research. YL supported ZW to build YL6-GFP in her lab. PM improved manuscript.

\section{ACKNOWLEDGMENT}

This work was supported by Shaanxi Science and Technology Research and Development Program (No. 2013K01-38).

\section{SUPPLEMENTARY MATERIAL}

The Supplementary Material for this article can be found online at: http://journal.frontiersin.org/article/10.3389/fmicb. 2017.01270/full\#supplementary-material

FIGURE S1 | Gram stain of YL6.

FIGURE S2 | Formation of a phosphate-solubilizing zone around the YL6 (left) and YL6-GFP (right) strains.

FIGURE S3 | Morphology of Chinese cabbage after the application of YL6 under field conditions.

FIGURE S4 | Growth curves of YL6 and YL6-GFP.

FIGURE S5 | Colonization of the YL6-GFP strain in soil (A: 3\% inoculum size; $\mathbf{B}$ $6 \%$ inoculum size; C: $9 \%$ inoculum size). 


\section{REFERENCES}

Ali, R. I., Awan, T. H., Ahmad, M., Saleem, M. U., and Akhtar, M. (2012). Diversification of rice-based cropping systems to improve soil fertility, sustainable productivity and economics. J. Anim. Plant Sci. 22, $108-112$.

Anand, R., and Chanway, C. P. (2013). Detection of GFP-labeled Paenibacillus polymyxa in autofluorescing pine seedling tissues. Biol. Fertil. Soils 49, 111-118. doi: 10.1007/s00374-012-0727-9

Asea, P. E. A., Kucey, R. M. N., and Stewart, J. W. B. (1988). Inorganic phosphate solubilization by two Penicillium species in solution culture and soil. Soil Biol. Biochem. 20, 459-464. doi: 10.1016/0038-0717(88)90058-2

Babu, A. N., Jogaiah, S., Ito, S., Nagaraj, A. K., and Tran, L. S. P. (2015). Improvement of growth, fruit weight and early blight disease protection of tomato plants by rhizosphere bacteria is correlated with their beneficial traits and induced biosynthesis of antioxidant peroxidase and polyphenol oxidase. Plant Sci. 231, 62-73. doi: 10.1016/j.plantsci.2014.11.006

Badawi, M. A. (2010). Role of phosphorus solubilizing microorganisms in the growth of date palm trees. Acta Hortic. 882, 115-120. doi: 10.17660/ActaHortic. 2010.882.12

Bashan, Y., Puente, M. E., Rodriguez-Mendoza, M. N., Toledo, G., Holguin, G., Ferrera-Cerrato, R., et al. (1995). Survival of Azospirillum brasilense in the bulk soil and rhizosphere of 23 soil types. Appl. Environ. Microbiol. 61, 1938-1945.

Best, E. K. (1976). An automated method for determining nitrate nitrogen in soil extracts. Qld. J. Agric. Anim. Sci. 33, 161-166.

Bonaldi, M., Chen, X., Kunova, A., Pizzatti, C., Saracchi, M., and Cortesi, P. (2015). Colonization of lettuce rhizosphere and roots by tagged Streptomyces. Front. Microbiol. 6:25. doi: 10.3389/fmicb.2015.00025

Brown, W. J., and Waatti, P. E. (1980). Susceptibility testing of clinically isolated anaerobic bacteria by an agar dilution technique. Antimicrob. Agents Chemother. 17, 629-635. doi: 10.1128/AAC.17.4.629

Bucher, M. (2007). Functional biology of plant phosphate uptake at root and mycorrhiza interfaces. New Phytol. 173, 11-26. doi: 10.1111/j.1469-8137.2006. 01935.x

Chalfie, M. (1994). Green fluorescent protein as a marker for gene expression. Science 263, 151. doi: 10.1126/science.8303295

Chatli, A. S., Beri, V., and Sidhu, B. S. (2008). Isolation and characterisation of phosphate solubilising microorganisms from the cold desert habitat of Salix alba Linn. in trans Himalayan region of Himachal Pradesh. Indian J. Microbiol. 48, 267-273. doi: 10.1007/s12088-008-0037-y

Chen, W., Yang, F., Zhang, L., and Wang, J. (2015). Organic acid secretion and phosphate solubilizing efficiency of Pseudomonas sp. PSB12: effects of phosphorus forms and carbon sources. Geomicrobiology 33, 870-877. doi: 10.1080/01490451.2015.1123329

Chen, W. L., Li, J., Zhu, H. H., Xu, P. Y., Chen, J. Z., and Yao, Q. (2017). The differential and interactive effects of arbuscular mycorrhizal fungus and phosphorus on the lateral root formation in Poncirus trifoliata (L.). Sci. Hortic. 217, 258-265. doi: 10.1016/j.scienta.2017.02.008

Chen, X., Pizzatti, C., Bonaldi, M., Saracchi, M., Erlacher, A., Kunova, A., et al. (2016). Biological control of lettuce drop and host plant colonization by rhizospheric and endophytic Streptomycetes. Front. Microbiol. 7:714. doi: $10.3389 /$ fmicb.2016.00714

Chen, Y. P., Rekha, P. D., Arun, A. B., Shen, F. T., Lai, W. A., and Young, C. C. (2006). Phosphate solubilizing bacteria from subtropical soil and their tricalcium phosphate solubilizing abilities. Appl. Soil Ecol. 34, 33-41. doi: 10.1016/j.apsoil.2005.12.002

Chong, L. (2001). Molecular cloning - A laboratory manual, 3rd edition. Science 292, 446-446. doi: 10.1126/science.1060677

Clarridge, J. E. (2004). Impact of 16S rRNA gene sequence analysis for identification of bacteria on clinical microbiology and infectious diseases. Clin. Microbiol. Rev. 17, 840-862. doi: 10.1128/CMR.17.4.840-862.2004

Coelho, M. M., Ferreira-Nozawa, M. S., Nozawa, S. R., and Santos, A. L. W. (2011). Isolation of endophytic bacteria from arboreal species of the Amazon and identification by sequencing of the 16S rRNA encoding gene. Genet. Mol. Biol. 34, 678-680. doi: 10.1590/S1415-47572011005000045

Colwell, J. D. (1963). The estimation of the phosphorus fertilizer requirements of wheat in southern New South Wales by soil analysis. Aust. J. Exp. Agric. 3, 190-197. doi: 10.1071/EA9630190
Coombs, J. T., and Franco, C. M. M. (2003). Visualization of an endophytic Streptomyces species in wheat seed. Appl. Environ. Microbiol. 69, 4260-4262. doi: 10.1128/AEM.69.7.4260-4262.2003

Crooke, W. M., and Simpson, W. E. (1971). Determination of ammonium in Kjeldahl digests of crops by an automated procedure. J. Sci. Food Agric. 22, 9-10. doi: 10.1002/jsfa.2740220104

Fernández, L., Agaras, B., Zalba, P., Wall, L. G., and Valverde, C. (2012). Pseudomonas spp. isolates with high phosphate-mobilizing potential and root colonization properties from agricultural bulk soils under no-till management. Biol. Fertil. Soils 48, 763-773. doi: 10.1007/s00374-012-0665-6

Fürnkranz, M., Müller, H., and Berg, G. (2009). Characterization of plant growth promoting bacteria from crops in Bolivia. J. Plant Dis. Prot. 116, 149-155. doi: 10.1007/BF03356303

Gamalero, E., Lingua, G., Caprì, G., Fusconi, A., Berta, G., and Lemanceau, P. (2004). Colonization pattern of primary tomato roots by Pseudomonas fluorescens A6RI characterized by dilution plating, flow cytometry, fluorescence, confocal and scanning electron microscopy. FEMS Microbiol. Ecol. 48, 79-87. doi: 10.1016/j.femsec.2003.12.012

Gammon, N. (1951). Determination of total potassium and sodium in sandy soils by flame photometer. Soil Sci. 71, 211-214. doi: 10.1097/00010694-19510300000009

Gilbertson, A. W., Fitch, M. W., Burken, J. G., and Wood, T. K. (2007). Transport and survival of GFP-tagged root-colonizing microbes: implications for rhizodegradation. Eur. J. Soil Biol. 43, 224-232. doi: 10.1016/j.ejsobi.2007. 02.005

Goldstein, A. H. (1951). Future trends in research on microbial phosphate solubilization: one hundred years of insolubility. Ugeskr. Laeger 113, 1618-1621.

Hameeda, B., Harini Grupela, O. P., Wani, S. P., and Reddy, G. (2008). Growth promotion of maize by phosphate-solubilizing bacteria isolated from composts and macrofauna. Microbiol. Res. 163, 234-242. doi: 10.1016/j.micres.2006. 05.009

Hanif, M. K., Hameed, S., Imran, A., Naqqash, T., Shahid, M., and Van Elsas, J. D. (2015). Isolation and characterization of a $\beta$-propeller gene containing phosphobacterium Bacillus subtilis strain KPS-11 for growth promotion of potato (Solanum tuberosum L.). Front. Microbiol. 6:583. doi: 10.3389/fmicb. 2015.00583

Heppell, J., Talboys, P., Payvandi, S., Zygalakis, K. C., Fliege, J., Withers, P. J. A., et al. (2015). How changing root system architecture can help tackle a reduction in soil phosphate (P) levels for better plant P acquisition. Plant Cell Environ. 38, 118-128. doi: 10.1111/pce. 12376

Ilany, T., Ashton, M. S., Montagnini, F., and Martinez, C. (2010). Using agroforestry to improve soil fertility: effects of intercropping on Ilex paraguariensis (yerba mate) plantations with Araucaria angustifolia. Agrofor. Syst. 80, 399-409. doi: 10.1007/s10457-010-9317-8

Jackson, M. L. (1958). Soil Chemical Analysis. New York, NY: Prentice-Hall.

Ji, S. H., Gururani, M. A., and Chun, S. C. (2014). Expression analysis of rice pathogenesis-related proteins involved in stress response and endophytic colonization properties of $g f p$-tagged Bacillus subtilis CB-R05. Appl. Biochem. Biotechnol. 174, 231-241. doi: 10.1007/s12010-014-1047-3

Kinraide, T. B., Parker, D. R., and Zobel, R. W. (2005). Organic acid secretion as a mechanism of aluminium resistance: a model incorporating the root cortex, epidermis, and the external unstirred layer. J. Exp. Bot. 56, 1853-1865. doi: $10.1093 /$ jxb/eri175

Kucey, R. M. N., Janzen, H. H., and Leggett, M. E. (1989). Microbially mediated increases in plant-available phosphorus. Adv. Agron. 42, 199-228. doi: 10.1016/ S0065-2113(08)60525-8

Lelis, F. M. V., Czajkowski, R., De Souza, R. M., Ribeiro, D. H., and Van Der Wolf, J. M. (2014). Studies on the colonization of axenically grown tomato plants by a gfp-tagged strain of Clavibacter michiganensis subsp michiganensis. Eur. J. Plant Pathol. 139, 53-66. doi: 10.1016/S0065-2113(08)60525-8

Li, X., Luo, L., Yang, J., Li, B., and Yuan, H. (2015). Mechanisms for solubilization of various insoluble phosphates and activation of immobilized phosphates in different soils by an efficient and salinity-tolerant Aspergillus niger strain An2. Appl. Biochem. Biotechnol. 175, 2755-2768. doi: 10.1007/s12010-014-1465-2

Liu, L. P., Deng, Z. N., Qu, J. W., Yan, J. W., Catara, V., Li, D. Z., et al. (2012). Construction of egfp-labeling system for visualizing the infection process of Xanthomonas axonopodis pv. citriinplanta. Curr. Microbiol. 65, 304-312. doi: $10.1007 / \mathrm{s} 00284-012-0155-\mathrm{y}$ 
Luby-Phelps, K., Ning, G., Fogerty, J., and Besharse, J. C. (2003). Visualization of identified GFP-expressing cells by light and electron microscopy. J. Histochem. Cytochem. 51, 271-274. doi: 10.1177/0022155403051 00301

Majeed, A., Abbasi, M. K., Hameed, S., Imran, A., and Rahim, N. (2015). Isolation and characterization of plant growth-promoting rhizobacteria from wheat rhizosphere and their effect on plant growth promotion. Front. Microbiol. 6:198. doi: 10.3389/fmicb.2015.00198

Mclachlan, K. D. (1980). Acid phosphatase activity of intact roots and phosphorus nutrition in plants.1. Assay conditions and phosphatase activity. Aust. J. Agric. Res. 31, 429-440. doi: 10.1071/ar9800429

Murphy, J., and Riley, J. P. (1962). A modified single solution method for the determination of phosphate in natural waters. Anal. Chim. Acta 27, 31-36. doi: 10.1016/S0003-2670(00)88444-5

Narendra, B. A., Jogaiah, S., Ito, S., Kestur, N. A., and Tran, L. S. (2015). Improvement of growth, fruit weight and early blight disease protection of tomato plants by rhizosphere bacteria is correlated with their beneficial traits and induced biosynthesis of antioxidant peroxidase and polyphenol oxidase. Plant Sci. 231, 62-73. doi: 10.1016/j.plantsci.2014.11.006

Nelson, D. W., and Sommers, L. E. (1996). "Total carbon, organic carbon, and organic matter," in Methods of Soil Analysis Part 3 Chemical Methods, eds J. M. Bartels, J. M. Bigham, D. L. Sparks, A. L. Page, P. A. Helmke, R. H. Loeppert et al. (Madison, WI: SSSA), 961-1010.

Olivain, C., Humbert, C., Nahalkova, J., Fatehi, J., L'haridon, F., and Alabouvette, C. (2006). Colonization of tomato root by pathogenic and nonpathogenic Fusarium oxysporum strains inoculated together and separately into the soil. Appl. Environ. Microbiol. 72, 1523-1531. doi: 10.1128/AEM.72.2.1523-1531. 2006

Osorio, N. W., and Habte, M. (2015). Effect of a phosphate-solubilizing fungus and an arbuscular mycorrhizal fungus on leucaena seedlings in tropical soils with contrasting phosphate sorption capacity. Plant Soil 389, 375-385. doi: 10.1007/s11104-014-2357-5

Paavilainen, S., and Korpela, T. (1993). Comparison of high-performance liquid and gas chromatography in the determination of organic acids in culture media of alkaliphilic bacteria. J. Chromatogr. A 634, 273-280. doi: 10.1016/00219673(93)83014-J

Padda, K. P., Puri, A., and Chanway, C. P. (2015). Effect of GFP tagging of Paenibacillus polymyxa $\mathrm{P} 2 \mathrm{~b}-2 \mathrm{R}$ on its ability to promote growth of canola and tomato seedlings. Biol. Fertil. Soils 52, 377-387. doi: 10.1007/s00374-0151083-3

Pokluda, R. (2008). Nutritional quality of Chinese cabbage from integrated culture. Hortic. Sci. 35, 145-150.

Poonguzhali, S., Madhaiyan, M., Yim, W. J., Kim, K. A., and Sa, T. M. (2008). Colonization pattern of plant root and leaf surfaces visualized by use of greenfluorescent-marked strain of Methylobacterium suomiense and its persistence in rhizosphere. Appl. Microbiol. Biotechnol. 78, 1033-1043. doi: 10.1007/s00253008-1398- 1

Prosser, J. I. (1994). Molecular marker systems for detection of genetically engineered micro-organisms in the environment. Microbiology 140(Pt 1), 5-17. doi: $10.1099 / 13500872-140-1-5$

Qin, Z. X., Li, Y., and Yu, Q. (2010). Determination of metabolic organic acids of bifidobacterium by HPLC. Mod. Prev. Med. 37, 320-323. doi: 10.1002/jsfa.5915

Ramachandran, K., Srinivasan, V., Hamza, S., and Anandaraj, M. (2007). "Phosphate solubilizing bacteria isolated from the rhizosphere soil and its growth promotion on black pepper (Piper nigrum L.) cuttings," in Proceedings of the First International Meeting on Microbial Phosphate Solubilization, Vol. 102, eds E. Velázquez and C. Rodríguez-Barrueco (Dordrecht: Springer), $325-331$.

Ri, P. (1948). Mobilization of phosphorus in soil in connection with the vital activity of some microbial species. Mikrobiologiya $17,362-370$.

Rodríguez, H., and Fraga, R. (1999). Phosphate solubilizing bacteria and their role in plant growth promotion. Biotechnol. Adv. 17, 319-339. doi: 10.1016/S07349750(99)00014-2

Rodríguez, H., Fraga, R., Gonzalez, T., and Bashan, Y. (2006). Genetics of phosphate solubilization and its potential applications for improving plant growth-promoting bacteria. Plant Soil 287, 15-21. doi: 10.1007/s11104-0069056-9
Sambrook, J., Fritsch, E. F., and Maniatis, T. (1989). Molecular Cloning: A Laboratory Manual. Cold Spring Harbor, NY: Cold Spring Harbor laboratory press, 931-957.

Schachtman, D. P., Reid, R. J., and Ayling, S. M. (1998). Phosphorus uptake by plants: from soil to cell. Plant Physiol. 116, 447-453. doi: 10.1104/pp.116.2.447

Schippers, B., Scheffer, R. J., Lugtenberg, B. J. J., and Weisbeek, P. J. (1995). Biocoating of seeds with plant growth-promoting rhizobacteria to improve plant establishment. Outlook Agric. 24, 179-185.

Seo, P. J., and Park, C. M. (2009). Auxin homeostasis during lateral root development under drought condition. Plant Signal. Behav. 4, 1002-1004. doi: $10.4161 /$ psb.4.10.9716

Shahid, M., Hameed, S., Imran, A., Ali, S., and Van Elsas, J. D. (2012). Root colonization and growth promotion of sunflower (Helianthus annuus L.) by phosphate solubilizing Enterobacter sp. Fs-11. World J. Microbiol. Biotechnol. 28, 2749-2758. doi: 10.1007/s11274-012-1086-2

Shahid, M., Hameed, S., Tariq, M., Zafar, M., Ali, A., and Ahmad, N. (2014). Characterization of mineral phosphate-solubilizing bacteria for enhanced sunflower growth and yield-attributing traits. Ann. Microbiol. 65, 1525-1536. doi: 10.1007/s13213-014-0991-z

Shane, M. W., De Vos, M., De Roock, S., and Lambers, H. (2003). Shoot P status regulates cluster-root growth and citrate exudation in Lupinus albus grown with a divided root system. Plant Cell Environ. 26, 265-273. doi: 10.1046/j.13653040.2003.00957.x

Shen, X., Chen, Y., Liu, T., Hu, X., and Gu, Z. (2013). Development of a highefficient transformation system of Bacillus pumilus strain DX01 to facilitate gene isolation via $g f p$-tagged insertional mutagenesis and visualize bacterial colonization of rice roots. Folia Microbiol. 58, 409-417. doi: 10.1007/s12223013-0223-0

Shenoy, V. V., and Kalagudi, G. M. (2005). Enhancing plant phosphorus use efficiency for sustainable cropping. Biotechnol. Adv. 23, 501-513. doi: 10.1016/ j.biotechadv.2005.01.004

Simons, M., Vanderbij, A. J., Brand, I., Deweger, L. A., Wijffelman, C. A., and Lugtenberg, B. J. J. (1996). Gnotobiotic system for studying rhizosphere colonization by plant growth-promoting Pseudomonas bacteria. Mol. Plant Microbe Interact. 9, 600-607. doi: 10.1080/09500830600815365

Singh, A. V., Prasad, B., and Shah, S. (2011). Influence of phosphate solubilizing bacteria for enhancement of plant growth and seed yield in lentil. J. Crop Weed $7,1-4$.

Singh, H., and Reddy, M. S. (2011). Effect of inoculation with phosphate solubilizing fungus on growth and nutrient uptake of wheat and maize plants fertilized with rock phosphate in alkaline soils. Eur. J. Soil Biol. 47, 30-34. doi: 10.1016/j.ejsobi.2010.10.005

Sneath, P. H. A., Mair, N. S., Sharpe, M. E., and Holt, J. G. (1986). Bergey's Manual of Systematic Bacteriology. New York, NY: Springer-Verlag.

Somasegaran, P., and Hoben, H. J. (1994). Handbook for Rhizobia: Methods in Legume-Rhizobium Technology. New York, NY: Springer-Verlag. doi: 10.1007/ 978-1-4613-8375-8

Steel, R. G. D., Torrie, J. H., and Dickey, D. A. (1981). Principles and Procedures of Statistics: A Biometrical Approach, 2nd Edn. New York, NY: McGraw-Hill, 441-441.

Takahashi, S., and Anwar, M. R. (2007). Wheat grain yield, phosphorus uptake and soil phosphorus fraction after 23 years of annual fertilizer application to an Andosol. Field Crops Res. 101, 160-171. doi: 10.1016/j.fcr.2006.11.003

Tan, Z. Y., Xu, X. D., Wang, E. T., Gao, J. L., Martinezromero, E., and Chen, W. X. (1997). Phylogenetic and genetic relationships of Mesorhizobium tianshanense and related rhizobia. Int. J. Syst. Bacteriol. 47, 874-879. doi: 10.1099/0020771347-3-874

Tao, G. C., Tian, S. J., Cai, M. Y., and Xie, G. H. (2008). Phosphate-solubilizing and -mineralizing abilities of bacteria isolated from soils. Pedosphere 18, 515-523. doi: 10.1016/S1002-0160(08)60042-9

Ulén, B., Bechmann, M., Fölster, J., Jarvie, H. P., and Tunney, H. (2007). Agriculture as a phosphorus source for eutrophication in the north-west European countries, Norway, Sweden, United Kingdom and Ireland: a review. Soil Use Manage. 23, 5-15. doi: 10.1111/j.1475-2743.2007.00115.x

Viruel, E., Lucca, M. E., and Siñeriz, F. (2011). Plant growth promotion traits of phosphobacteria isolated from Puna. Argentina. Arch. Microbiol. 193, 489-496. doi: 10.1007/s00203-011-0692-y 
Wagh, J., Bhandari, P., Shah, S., Archana, G., and Kumar, G. N. (2014). Overexpression of citrate operon in Herbaspirillum seropedicae Z67 enhances organic acid secretion, mineral phosphate solubilization and growth promotion of Oryza sativa. Plant Soil 383, 73-86. doi: 10.1007/s11104-014-2161-2

Yin, Y. (2011). Screening of PhosPhorus-Solubilizing Strain and its PhosPhate Dissolving Mechanism. Master dissertation, Dalian University of Technology, Dalian.

Yu, X., Liu, X., Zhu, T. H., Liu, G. H., and Mao, C. (2011). Isolation and characterization of phosphate-solubilizing bacteria from walnut and their effect on growth and phosphorus mobilization. Biol. Fertil. Soils 47, 437-446. doi: 10.1007/s00374-011-0548-2

Zhao, K., Penttinen, P., Zhang, X. P., Ao, X. L., Liu, M. K., Yu, X. M., et al. (2014). Maize rhizosphere in Sichuan, China, hosts plant growth promoting Burkholderia cepacia with phosphate solubilizing and antifungal abilities. Microbiol. Res. 169, 76-82. doi: 10.1016/j.micres.2013.07.003

Zhao, L. F., Xu, Y. J., Ma, Z. Q., Deng, Z. S., Shan, C. J., and Wei, G. H. (2013). Colonization and plant growth promoting characterization of endophytic Pseudomonas chlororaphis strain Zong1 isolated from Sophora alopecuroides root nodules. Braz. J. Microbiol. 44, 629-637. doi: 10.1590/S151783822013000200043

Zimmer, M. (2002). Green fluorescent protein (GFP): applications, structure, and related photophysical behavior. Chem. Rev. 102, 759-781. doi: 10.1021/ cr010142r

Conflict of Interest Statement: The authors declare that the research was conducted in the absence of any commercial or financial relationships that could be construed as a potential conflict of interest.

Copyright (c) 2017 Wang, Xu, Ma, Lin, Yang and Cao. This is an open-access article distributed under the terms of the Creative Commons Attribution License (CC BY). The use, distribution or reproduction in other forums is permitted, provided the original author(s) or licensor are credited and that the original publication in this journal is cited, in accordance with accepted academic practice. No use, distribution or reproduction is permitted which does not comply with these terms. 